\title{
An Analysis of College English Classroom Questioning
}

\author{
Weihua $\mathrm{Yu}$ \\ Qingdao University of Science and Technology, Qingdao, China \\ Email: yuweihua961126@163.com
}

\begin{abstract}
The analysis of classroom interaction is a very important form which classroom process research has taken. The present study focuses on college English classroom questioning. Through a detailed description and analysis of the collected data, types of questions and modification techniques are made clear and on the basis of which a few strategies for college English teachers are put forward by the author in order to improve college English teaching and learning.
\end{abstract}

Index Terms - college English, questioning, modification

\section{INTRODUCTION}

Since spoken language is "the medium by which much teaching takes place and in which students demonstrate to teachers much of what they have learned"(Cazden,1987, cited from Wittrock,1988), the application of discourse analysis to second language teaching and learning can reveal much about how teachers can improve their teaching practices by investigating actual language use in the classroom, and how students can learn language through exposure to different types of discourse . Nunan has pointed that "If we want to enrich our understanding of language learning and teaching, we need to spend time looking in classroom"(Nunan, 1989:76). According to researchers of communicative teaching, "failed communication is a joint responsibility and not the fault of speaker or listeners. Similarly, successful communication is an accomplishment jointly achieved and acknowledged" (Jack C. Richards and Theodore S.Rodgers, 2000: 77 ); "It is the teachers' responsibility to organize the classroom as a setting for communication and communicative activities"(Jack C. Richards and Theodore S.Rodgers,2000:78 ). In recent years, a much greater role has been attributed to interactive features of classroom behaviors, such as "turn-taking, questioning and answering, negotiation of meaning, and feedback" (Chaudron, 1988:10). In second language classrooms, "learners often do not have a great number of tools..., teachers' questions provide necessary stepping stones to communication" (Brown, 1994a: 165). Questioning is reported as one of the commonly used strategies, as the success of a class largely depends on questioning and feedback.

The problem which is going to be mainly investigated here is types of teachers' questions and teachers' modifying strategies in a class. Because "two of the most common ways in which L2 teachers engage in interaction with learners is by way of asking questions and providing feedback, and these deserve some consideration" (Holland and Shortall, 1997:104), focusing on them can be expected to show useful findings which will contribute to deeper insights about the ways to improve $\mathrm{L} 2$ teaching and learning.

The context specified here is a college English classroom of non-English major. College English refers to English learned by Chinese college students whose major is other than English. The data are collected from three college English classrooms of non-English major at Qingdao University of Science and Technology. This study is significant in that it reveals the characteristics of classroom interaction that is most favorable for promoting learners' English and has insightful implications for English teaching and learning.

\section{LITERATURE REVIEW}

\section{A. Teacher's Questions}

1 Importance and necessity of questioning

Much of teachers' talk relates to questions (Holland,R.and T.Shortall,1997:65)and substantial research exists demonstrating that questions can assist learners in improving their linguistic ability (McDonough and Shaw,1993:271-2). Chaudron (Chaudron, 1988:131) goes further, warning that poor questioning practice can be counter-productive. The importance of "careful framing of questions" according to Brown (Brown, 2001:169) sets a "learning climate for interactive teaching". He considers a teacher's questioning strategies (Brown, 2001: 173) "as one of the most important teaching behaviors to master". Richards and Lockhart conclude that teachers' questions "play a crucial role in language acquisition"(Richards and Lockhart, 1996:185). Ideally, questions should stimulate, interest, encourage, focus, help clarify, elicit, help check understanding, all positive achievements as stated in Richards and Lockhart (Richards and Lockhart, 1996:185).

2 Different taxonomies of questions 
Teachers' questions are one topic that has attracted many researchers' attention these days (Nunan, 1989). Much that defines questioning lies in the features of questions and of their purpose in classroom interaction. "Much of the work, on questions has centred in developing taxonomies to describe the different types" (Ellis, 1994:587). Several ways of distinguishing on question types have been developed by researchers in the seventies (e.g.Kearsley, 1976) and eighties (e.g. Hakasson \&Lindberg, 1988) and they are still being developed. One of the taxonomy is the framework of Long \&Sato (Ellis, 1994). It has seven sub-categories under two headings of types; 1 Echoic Types: a) comprehension checks, b)clarification requests, c) confirmation checks, 2 Epistemic Types: a)referential, b)display, c)expressive, d)rhetorical. In fact, both Chaudron (Chaudron, 1988:126-7) and Nunan (Nunan, 1989:30) cited in their books a general taxonomy of question types, which is given in table 1.

TABLE 1

TAXONOMY OF QUESTION TYPES.

\begin{tabular}{|c|c|c|}
\hline Question Type & Explanation & Noted by \\
\hline Closed & have a short, fixed answer, for example "What day is it today?" & Barnes (1969) \\
\hline Open & $\begin{array}{c}\text { typically require a longer, less limited response, for example "What did } \\
\text { you do yesterday?" }\end{array}$ & \\
\hline Display & $\begin{array}{l}\text { those to which the questioner already knows the answer and is merely } \\
\text { testing the respondent's knowledge or understanding. }\end{array}$ & Brown (1994a: 165) \\
\hline Referential & $\begin{array}{l}\text { those to which the questioner does not know } \\
\text { the answer and is genuinely seeking information. }\end{array}$ & \\
\hline Procedural & $\begin{array}{l}\text { relate to classroom, lesson and student control processes such as "Who is } \\
\text { absent today? }\end{array}$ & $\begin{array}{c}\text { Richards and } \\
\text { Lockhart(1996:186-7) }\end{array}$ \\
\hline Convergent & $\begin{array}{c}\text { often have short answers which "encourage } \\
\text { similar student responses" and require low } \\
\text { level thought processing, for example "Can } \\
\text { you ski ?_-"Yes, I can", "No, I can't". }\end{array}$ & \\
\hline Divergent & $\begin{array}{l}\text { necessitate more wide-ranging, longer responses with higher level thought } \\
\text { processing for example "Why is the Beatles' music so popular in Japan?" }\end{array}$ & \\
\hline Rhetorical & those which the questioner answers him/herself. & \\
\hline \multirow[t]{3}{*}{ Interaction } & $\begin{array}{c}\text { Comprehension: elicits } \\
\text { assurance from the listener that } \\
\text { a message has been received correctly. }\end{array}$ & Chaudron (1988:130-1) \\
\hline & $\begin{array}{l}\text { Confirmation checks: assume a positive } \\
\text { response and "allow the speaker to } \\
\text { correctly interpret reactions by the listener" }\end{array}$ & \\
\hline & $\begin{array}{c}\text { Clarification requests: similar to } \\
\text { confirmation requests but with a more open answer. }\end{array}$ & \\
\hline Instructional & $\begin{array}{l}\text { Any question presented in the classroom. Presupposes that the question is } \\
\text { intended to solicit learner production. }\end{array}$ & Van Lier(1988:223) \\
\hline Conversational & Any question asked outside the classroom. & \\
\hline
\end{tabular}

Display refers to questions for which the teacher knows the answer and which demand a single or short response of the low-level thinking kind. Referential questions, by contrast, demand more thought and generate longer responses and for which the teacher does not know the answer in advance. Richards and Lockhart (Richards and Lockhart, 1996:185-187) divide questions into three useful categories: procedural related to classroom procedures such as "Do you know what to do?"; convergent, which requests a short answer around a specific theme such as "Do kids help out with the housework?"; divergent questions, the last, are like referential questions as in "Sally, what do you think?". Their categories differ from the simple display/referential variety in that convergent questions include those to which a teacher may not know the answer but which narrow the range of possible responses, most notably closed questions demanding a yes or no answer.

\section{B. Modifying Strategies}

Among others, Krashen (1982a: 33) quoted in Larsen-Freeman and Long

(Larsen-Freeman and Long, 1991:224) has coined the term comprehensible input and teachers often modify their speech on the assumption that this enhances comprehensibility. Chaudron (Chaudron, 1988: 55) argues that this heightened comprehensibility maintains communication. After that, other writers, such as Nunan (Nunan, 1991:134-9), Richards and Lockhart (Richards and Lockhart, 1994:182-4) and Larsen-Freeman and Long (Larsen-Freeman and Long, 1991:134-9) have based their own discussions on Chaudron's analysis. The chief work available which reviews and collates research on modification techniques is Chaudron (Chaudron, 1988: 54-86), who gives a taxonomy of modification techniques, including modified pronunciation, pauses, repetition, rate of speech and so on.

But use of different measures or methods has often led to contradictory findings on the efficacy of modifications. For example, it is unclear whether modified length of utterance aids comprehension because utterances have been variously measured as words per utterance, sentence or T-unit (Holland and Shortall, 1997: 68 and Chaudron, 1988:73).

Research on repetition and rephrasing, the most commonly employed modifications (Chaudron, 1988:127), also appears to give little consensus. The former was found to aid immediate recall (Cervantes, 1983, cited from Chaudron, 1988:156), though immediate recall may not equate to comprehension. There are also doubts as to the efficacy of the 
latter (Chaudron, 1988: 128). Chaudron (Chaudron, 1988: 157) concludes from his analysis that: Although more research is clearly called for, with more explicit tests of syntactic complexity in L2 listening comprehension, the current results do not look promising. The other factors involved in simplification of input, namely, elaborations by the way of redundancy - restatements, repetition, synonyms, and so on - need to be more extensively examined.

Wait-time is a type of pause in the teacher's discourse and research has found that increased wait-time can be beneficial. Firstly, learners have more time to process the question and to formulate a response (Chaudron, 1988:128). Secondly, more learners attempt to respond (Richards and Lockhart, 1996: 188). Also, "the length and complexity of the response increases" (Holley and King, 1971, cited from Nunan, 1991: 193).

\section{DATA COLLECTION AND ANALYSIS}

\section{A. Data Collection}

The data were collected in three college English intensive reading classes of non-English majors in Qingdao University of Science and Technology where the college English teaching and learning has always been the center of attention because of college English test Band 4. As a teacher of college English, the study of college English classroom questioning is of great interest to me in that I want to know what really goes on in our own classrooms and what I can do to improve college English teaching and learning.

The three classes which were observed and recorded from September to November were band 1 college English classes from different departments with about sixty students in each one. The majority of the students have studied English for 6 years although there is considerable difference in level because they came from different places with different level of English teaching. The three teachers in these classes had 5-6 years of teaching experience. The text book used was "New Horizon College English (I)" which is designed to train students' listening, speaking, reading, writing, translating ability with the reading ability as a priority. So the classes chosen here are all intensive reading classes.

Nunan (Nunan ,1989:76) said " there is no substitute for direct observation as a way of finding out about language classrooms", therefore in this study ,the author came into the classroom personally to observe. The observation was conducted in six classes; about 5 hours (50 minutes for each class) were observed and recorded, 3 of which were transcribed and used for analysis, then allowing as many patterns of behavior and inconsistencies as possible to emerge. After class, the author had an interview with the students, knowing more about their ideas and feeling about their teacher and class. Consequently, in order to collect quantitative and qualitative data needed for the analysis, the method employed was that of ethnographic research, and audio recording and field notes were applied as well.

\section{B. Data Analysis and Discussion}

\section{Analysis of types of questions}

According to the taxonomy of question types mentioned above, questions were counted and multiple-coded. For example, "who is absent today" can be both procedural and referential. In addition, in one of the classes I observed, the teacher had one to one practice at the beginning of the class, so data for teacher's behavior during instruction and practice are presented separately to maximize the data's indicative power.

1.1 Results

The result of the data analysis is shown in Tables 2-6

TABLE 2

FREQUENCY AND ALLOCATION OF QUESTION TYPES IN CLASS ONE DURING INSTRUCTION

\begin{tabular}{|c|c|c|}
\hline Question type & Frequency of use & Equivalent percentage \\
\hline Open & & $15.56 \%$ \\
\hline Closed & 7 & $28.89 \%$ \\
\hline Display & 13 & $13.33 \%$ \\
\hline Referential & 6 & $40 \%$ \\
\hline Convergent & 18 & \\
\hline Divergent & & \\
\hline Rhetorical & 1 & \\
\hline Procedural & & \\
\hline Interaction & & \\
\hline
\end{tabular}


TABLE 3

FREQUENCY AND ALLOCATION OF QUESTION TYPES IN CLASS TWO DURING INSTRUCTION

\begin{tabular}{|c|c|c|}
\hline Question type & Frequency of use & Equivalent percentage \\
\hline Open & 1 & $3.45 \%$ \\
\hline Closed & 5 & $17.24 \%$ \\
\hline Display & 8 & $27.59 \%$ \\
\hline Referential & 5 & $17.24 \%$ \\
\hline Convergent & 9 & $31.03 \%$ \\
\hline Divergent & 1 & $3.45 \%$ \\
\hline Rhetorical & & \\
\hline Procedural & & \\
\hline Interaction & & \\
\hline
\end{tabular}

TABLE 4

FREQUENCY AND ALLOCATION OF QUESTION TYPES IN CLASS THREE DURING INSTRUCTION

\begin{tabular}{|c|c|c|}
\hline Question type & Frequency of use & Equivalent percentage \\
\hline Open & 8 & $17.02 \%$ \\
\hline Closed & 15 & $31.93 \%$ \\
\hline Display & 4 & $8.52 \%$ \\
\hline Referential & 20 & $42.55 \%$ \\
\hline Convergent & & \\
\hline Divergent & & \\
\hline Rhetorical & & \\
\hline Procedural & & \\
\hline Interaction & & \\
\hline
\end{tabular}

TABLE 5

FREQUENCY AND ALLOCATION OF QUESTION TYPES IN CLASS TWO DURING PRACTICE

\begin{tabular}{|c|c|c|c|c|c|c|}
\hline \multirow[t]{2}{*}{ Question type } & \multicolumn{5}{|c|}{ To individual student } & \multirow[t]{2}{*}{ percentage } \\
\hline & No.1 & No. 2 & No. 3 & No.4 & No.5 & \\
\hline \multicolumn{7}{|l|}{ Open } \\
\hline \multicolumn{7}{|l|}{ Closed } \\
\hline Display & & 1 & 1 & 1 & & $13.64 \%$ \\
\hline Referential & 2 & 1 & 1 & 2 & 2 & $36.36 \%$ \\
\hline Convergent & 1 & 2 & 3 & 2 & 3 & $50 \%$ \\
\hline \multicolumn{7}{|l|}{ Divergent } \\
\hline \multicolumn{7}{|l|}{ Rhetorical } \\
\hline \multicolumn{7}{|l|}{ Procedural } \\
\hline Interaction & & & & & & \\
\hline
\end{tabular}

TABLE6

TARGET OF TEACHER'S QUESTIONING

\begin{tabular}{|c|c|c|c|c|}
\hline & \multirow[t]{2}{*}{ Whole class } & \multicolumn{2}{|c|}{ Individual } & \multirow[t]{2}{*}{ Total } \\
\hline & & & Roll call & \\
\hline Class one & $71.05 \%$ & 0 & $28.95 \%$ & $100 \%$ \\
\hline Class two & $85.7 \%$ & 0 & $14.3 \%$ & $100 \%$ \\
\hline Class three & $82.11 \%$ & 0 & $17.89 \%$ & $100 \%$ \\
\hline
\end{tabular}

(excluding one to one practice phase in class two)

\subsection{Discussion}

The above tables show that during instruction teachers used procedural, open, closed, display, convergent and referential questions. Appendix A gives examples of procedural, convergent use (Lines 1, 10 and 12 respectively). Lines 30 and 44 exemplify questions which are both closed and display because there is only one correct response and at the same time the teacher knew the answers. Several such questions appear, but in line with Chaudron (Chaudron, 1988: 173) generated only the briefest and simplest of possible responses, sometimes even no response, of which those seen in lines 31, 45 are highly typical.

Referential questions also account for certain percentage even if lower. Although referential questions may encourage students to try harder to respond (Nunan, 1989:30), counter to Chaudron (Chaudron, 1988:127), this additional effort does not necessarily lead to higher quality communication if the question is also convergent in appearance, yielding highly similar, brief, relatively undemanding responses, which can be seen in the following example:

( the teacher in class three is explaining the text)

$\mathrm{T}$ : In paragraph 2, there is "internet purchase supplier". Could you translate?

PP: (silence)

T: It means "wang shang gong huo shang (Chinese)". Ok, Do you think it's convenient to shop online?

PP: Yes.

T: Do you often shop online? ( pause) Do you often shop online? Huangwei(Chinese name)

P1: No, I don't. 
T: Yes, No, I don't shop online. Do you often shop online? And Huangwei(Chinese name) answered "No, I don't.". Please answer the same question. Do you often shop online?

Xiao shengzhuan(Chinese name)

P2: No, I don't.

T: No, I don't. The same answer. Couldn't you tell us more?

Obviously, the question "Do you often shop online?" is a convergent question in appearance, but in nature, it is also a referential question. The teacher attempted to generate more language from the student, but he failed.

This finding also illustrates how the multiple coding of questions can provide additional information and may be a useful tool in future research.

We have noticed that students are not active in responding to the teacher. Why students minimize responses when they may be capable of lexically or syntactically more complex answers (for example, "No, I don't shop online. I usually go shopping in the market.) is unclear. One clue came from the stimulated response interview (Appendix C) with the students which revealed their desire to provide responses using as much acquired language (presumably lexical and syntactic) as possible. They conceded however that this was not always possible due to a perceived time pressure and the desire to maintain the flow of communication.

In conclusion, the overwhelming frequency of convergent and display questions shown in tables 2-5 and the great amount of closed questions among them is remarkable. The numbers suggest teachers' questioning strategies are less "natural", and demand lower-level thinking and provide less comprehensible input to students than divergent questions would have. It can also be inferred that the teacher exercises a strong control over what and how much is being said.

But we also noticed in table6 that in one to one practice, type range narrowed exclusively to display, referential and convergent questions, such as "Could you explain in English " and "When are you often cautious?" (Appendix B). The fact that more referential and convergent questions appear during the practice phase compared with more display and closed questioned during instruction is unexpected, but it is still comprehensible. The difference may be largely accounted for by the questions' purpose. During the instructional phase questions were used to warm-up and to teach and check learners' understanding of the linguistic items they would need to complete the practice successfully. A systematic sequence of short answer questions could achieve this goal relatively quickly and effectively and the teacher perceived no need to enter into extended discourse to achieve it.

Conversely, questions during practice mimicked those of a communicative drama. Maybe the teacher believes Thornbury's (Thornbury, 1996: 281) proposal that referential questions dominate "real-life" situations.

This teacher is attempting to fulfill two apparently mutually exclusive objectives, namely:

a) the need to teach the prescribed materials in preparation for written exams and

b) a desire to create 'realistic' situations in which students can practice speaking.

The implication here is that when selecting the range and differential use of questions, teachers may need to compromise their personally held beliefs regarding language use with the objectives of the EF program.

In terms of target of teacher's questioning, as can be seen from Table6, whole class activities dominated in all these three classes. Choral response was a fairly frequent event in the classroom perhaps for the reason that all these three classes were large classes of about 60 students in which it was impossible for all the students to have an opportunity to speak in public. Thus teachers tended to ask the whole class to answer them together. When questioning was directed against individual students, they almost always kept silent, unwilling to respond to the teacher. Sometimes teachers gave answers by themselves; if teachers insisted on getting students' answers, then roll call was needed. We have also noticed that during the instruction, display and convergent questions dominated, even if there existed referential questions, they are not absolutely genuine questions which really seek information, because teachers mostly aimed at eliciting language from students, therefore in most cases answers are easy to find if students can devote themselves to the class, which can be shown by the fact that most of nominated students could give correct answers. As a result, the passive and unwilling phenomenon is probably because students' negative attitude toward speaking English in front of others due to the fear of making mistakes. From this point, teachers should take effective measures to encourage students and relax them, solving their psychological problem, then more interaction between teachers and students may appear in EFL classrooms.

\section{Analysis of Teachers' Modification Technique}

\subsection{Results}

According to the taxonomy of modification techniques mentioned above, data collected were analyzed. But one technique not classified is perhaps the most obvious: translation of speech into L1, which is also studied here. The result is shown in the following tables.

TABLE7

FREQUENCY OF QUESTION REPETITIONS DURING INSTRUCTION

\begin{tabular}{|c|c|c|c|}
\hline & Frequency of repetition & Total numbers of questions & percentage \\
\hline Class one & 2 & 38 & $5.26 \%$ \\
\hline Class two & 3 & 23 & $13.04 \%$ \\
\hline Class three & 3 & 39 & $7.69 \%$ \\
\hline Mean frequency of repetition & & & $8.66 \%$ \\
\hline
\end{tabular}


TABLE 8

FREQUENCY OF QUESTION REPETITIONS DURING PRACTICE IN CLASS TWO

\begin{tabular}{|c|c|c|}
\hline Frequency of repetition & Total & percentage \\
\hline 2 & 21 & $9.52 \%$ \\
\hline
\end{tabular}

TABLE 9

CODE SWITCHING DURING INSTRUCTION IN CLASS ONE

\begin{tabular}{|c|c|c|}
\hline Domain & Frequency of use & percentage \\
\hline Code switching for questions & 2 & $5.26 \%$ \\
\hline Code switching for other discourse & 14 & \\
\hline
\end{tabular}

TABLE 10

CODE SWITCHING DURING INSTRUCTION IN CLASS TWO

\begin{tabular}{|c|c|c|}
\hline Domain & Frequency of use & percentage \\
\hline Code switching for questions & 3 & $13.04 \%$ \\
\hline Code switching for other discourse & 9 & \\
\hline
\end{tabular}

TABLE 11

CODE SWITCHING DURING INSTRUCTION IN CLASS THREE

\begin{tabular}{|c|c|c|}
\hline Domain & Frequency of use & percentage \\
\hline Code switching for questions & 3 & $7.69 \%$ \\
\hline Code switching for other discourse & 13 & \\
\hline
\end{tabular}

TABLE 12

CODE SWITCHING DURING PRACTICE IN CLASS TWO

\begin{tabular}{|c|c|c|}
\hline Domain & Frequency of use & percentage \\
\hline Code switching for questions & 1 & $4.76 \%$ \\
\hline Code switching for other discourse & 2 & \\
\hline
\end{tabular}

TABLE 13

MEAN WAIT-TIME FOR QUESTIONS DURING INSTRUCTION

\begin{tabular}{|c|c|c|}
\hline & Wait-time in raw data(seconds) & Mean wait-time \\
\hline Class one & $0,3,0,4,3,5,7,0,5,6,4,0,2,2,2,4,6,4,5,3,2,5$, & 2.71 \\
& $2,4,0,0,4,3,0,3,0,5,2,2,2,3,2,4$ & 2.86 \\
\hline Class two & $5,4,4,7,3,3,0,4,0,2,0,3,5,3,4,2,0,3,2,5,3,2,2$ & \\
\hline Class three & $4,2,2,4,5,0,2,2,4,3,6,2,2,6,2,4,5,4,3,2,2,0,4,3,3,5,5,3,0,2,3,5,2,0,4,3,3,2,0$ & \\
\hline
\end{tabular}

TABLE 14

MEAN WAIT-TIME FOR QUESTIONS DURING PRACTICE

\begin{tabular}{|c|c|c|}
\hline & Wait-time in raw data(seconds) & Mean wait-time \\
\hline $\begin{array}{c}\text { Class } \\
\text { two }\end{array}$ & $0,2,4,2,2,4,2,4,0,2,3,0,5,0,2,3,3,2,2,4,5$ & 2.43 \\
\hline
\end{tabular}

\subsection{Discussion}

As can be seen in the above tables, techniques employed during both instruction and practice included repetition, code switching and pauses. During instruction, the mean frequency of repetition makes up 8.66\%, while $9.52 \%$ during practice. The copious repetitions of "Do you often shop online?" were intended not only to increase comprehensibility but also to maximize the opportunities for students to produce English. With only $8.66 \%$ of questions being repeated, this was counter to Chaudron's result of research (Chaudron, 1988:127) "predominant modification technique". This was probably because (a) most of questions are very easy to understand, so it is unnecessary to repeat; (b) there is much work to do in class, and the teacher wants to save more time to complete the task.

A point of interest here is that the teacher also repeated very easy questions, such as "what does 'enhance' mean?". This may have been a way of attracting students' attention or a way of avoiding unwanted silence in classroom.

Code switching for questions during instruction is another modification technique, although its percentage is low, making up only $8.66 \%$ on average. In addition, as shown in tables 9-11 code switching for general utterance appears more frequent than that for questions ( 2 times in class one, 3 times in class two, 3 times in class three), with 14 times in class one, 9 times in class two and 13 times in class three. Obviously, by using code switching, teachers want to make sure that students understand his utterances, e.g. Do you know it's antonym? Fan yi ci(Chinese)? "make cold" shi bian leng, leng cang(Chinese) etc.(Appendix A). It's true that teacher's translation of so many utterances into Chinese certainly aids comprehension, but at what cost? A disadvantage is that it seems to sanction use of L1 from students (Bruck and Schultz, 1977, cited from Chaudron, 1988:172 and Zilm, 1989, cited from Nunan,1991: 190), lines 30 and 31 in Appendix A being a case in point. The student replied in Chinese, even though they were almost certainly capable of the English equivalent. The implication for teachers is that they should attempt to maximize input in the target language wherever possible.

Code switching was less evident during practice, appearing only once for questions and twice for general utterances. The lower percentage $(4.76 \%)$ is perhaps because all the required elements had been thoroughly drilled and students could understand almost all items the teacher planned to review and check. 
Wait-times shown in tables 13-14 illustrate teachers' intention to give students more processing time for more difficult questions, for example, the question “could you express in English?"(Appendix A) waited for six seconds. But such long wait-time is very few as shown in tables 13-14, with 2.71 seconds in class one, 2.86 seconds in class two, 2.84 seconds in class three and 2.43 seconds during practice. Obviously, wait-times in these classes observed were shorter than in other teaching contexts (Holley and King proposed 5 seconds or more (Chaudron, 1988: 128)) .The reason for this is perhaps that (a) teachers need more time to finish their large amount of planned work keeping pace with teaching plan.(b) just as we mentioned above, most of students were inactive when needed to speak English in front of their classmates, even if extended wait-time couldn't encourage greater learner production, which is in line with Holley and King (Chaudron,1988).Lines 20-22 in Appendix A is a case in point. The teacher's question "what does the sentence mean?" should be easy to answer for most of students, because the sentence "people applauded lively for the president's speech" is not difficult with the word "applaud" in the new word list. But five seconds later, students still kept silent. Since teachers knew their students well, long wait-time is unnecessary, and shorter wait-time in this study is then understandable. Nevertheless, one of our teaching purposes is to improve students' spoken English. Therefore in our English classrooms teachers should surmount difficulties and take effective measures, trying their best to activate students into communication instead of conniving at their keeping silent.

In a word, three types of modification techniques were employed here. The utilization of a narrow range of relatively simple modification is no indicator as to the teachers' ability in this area but may be a selective use from a larger scope of skills.

\section{INSPIRATION FROM THE PRESENT STUDY}

Based on the study above, the following strategies are suggested for the college English teachers to refer to for the purpose of sustaining student engagement and communicative interaction in classrooms:

1) Asking "referential" questions and giving "positive" feedback.

The study result tells that referential questions accounted for only about $13.03 \%$ on average, showing teachers requested much more pseudo information (86.97\%) than genuine information (13.03\%) in asking questions, and it indicates that the communication between teacher and students was more of the pseudo-communication instead of real communication. Therefore, teachers should intentionally resort more to "referential questions" in which students have the opportunity of giving more information and talking more.

2) Maximize opportunities for students' participation

The above data analysis tells us it was the teacher who was dominating the classroom. The teacher did the most talk and controlled the topic. In this way the students were passive---they answered questions and got information passively from the teacher. The teacher should bear in mind that it is students who are learning language; therefore maximizing opportunities for students' participation to let them dominate the classroom is very necessary and important. Such target can be reached by such activities as role-play, story telling, debating, holding seminars and making presentations etc. In a word, enlarging students' portion in classroom and letting the learners dominate their own classroom, with the teachers only playing the role of a guide and an organizer is a challenging but beneficial aim, which is also the direction to which teachers in college English classrooms are working.

As a college English teacher, you can refer to these strategies to activate more students into communicative teaching activities in classrooms for the purpose of improving college English teaching and learning.

\section{APPENDIX A}

(The lesson in class one has just started and the teacher is taking the register)

I 1 T: Monitor, who is absent today?

R 2 P1: Zhangming.

I 3 T: Do you know the reason?

R 4 P1: Yes, 他病了, 这是他的假条。

I 10 T: Look at the second line in the first paragraph. Have you found the word "chill"?

R 11 PP: Yes.

I 12 T: Obviously, “chill” here is a verb, meaning “make cold”, 使变冷, 冷藏。For example, “chill the fruit plate before eating" Could you please translate?

13 PP: (silence)

...........

F 20 T: Ok, next paragraph. The word “ applaud”, for example “people applauded lively for the President's speech" [ the teacher turned back and wrote it down on the blackboard]

I What does the sentence mean?

21 PP: (silence)

Ib $22 \mathrm{~T}$ : 张芳 
I 30 T: And also there is the word "remark". What is its noun form?

Ib 它的名词形式是......

R 31 PP: 原形.

Ib 40 T: Sorry, I can’t. 刘沛, what about you?

\section{APPENDIX B}

(The lesson in class two has just started)

1 T: Ok, class begins. Last class, we finished learning Section A. Have you finished exercises in this passage?

2 PP: Yes.

3 T: Ok, good! Let's check to see how well you have done. Number one, in the first line in paragraph one, the word “cautious", 赵满, what does it mean?

4 P1: 小心的

$5 \mathrm{~T}$ : Yes, 小心的, 谨慎的. When are you often cautious?

6 P1: (silence)

7 T: When are you often cautious?

8 P1: When I walked in the street at night.

9 T: Good. You mean "When you walked in the street at night, you are cautions". The second one, "portly", could you find its synonym? 同义词? 杨凤英

10 P2: fat

11 T: Yes, fat. Do you like to be a portly girl?

12 P2: No, I don't.( laughter)

13 T: Why not?

14 P2: eh...

15 T: Certainly you want to be slim; you want to look pretty. Right?

16 P2: Right! ( laughter)

17 T: Ok, Let's go on, the sentence “contriving as I did so to toss my keys”, 李永亮，“contriving to toss”, do you know its meaning?

18 P3: 努力扔掉

19 T: Good. 努力扔掉. Could you explain in English?

20 P3: manage to do; try to do

21 T: Good. You did well. But I'm sure you know the difference between " manage to do" and " try to do" .Right?

22 P3: Right, "manage to do"

23 T: Ok, That's right. Before our final exam, what do you plan to contrive to do? Especially with many new words in this book?

24 PP:(silence)

25 T: You should contrive to remember as many new words and phrases as possible. Do you think so?

26 PP: Yes!

T: That's true. Large vocabulary is very important for you, especially

in the first year. Ok, next. "as if attached to unseen wires", 孟雪梅, could you translate the sentence?

27 P4: 好像接在看不见的电线上.

T: Good. "be attached to", “接在......上”. Do you think it has other meaning?

28 P4: “依恋......”

29 T: Good. “依恋......”, for example?

30 P4: He is attached to his mother.

31 T: Very good. The last one “hold dear", can you still remember this phrase? 姜雪莲

32 P5: Yes, 珍视, 重视.

33 T: In English?

36 P5: (silence)

T: "Value". What do you value now most?

34 P5: Eh...

35 T: Do you think we should hold dear our present life?

36 P5: Yes. We should because peace is important to us.

37 T: Very good. Ok, next, Let's talk about Reading Skills in Section B. 
(The interview was made in Chinese in the classroom. Later it was transcribed in English)

$1 \mathrm{~T}$ : I was interested in the answers you gave in the class. Many students use very short answers, for example, the question "Do you often shop online?", most of you answered "No, I don't". Can you give longer answers than that? Because it is not very difficult for you.

2 P1: I think I can use more English. I'd like to use more English but normally we use short answers, so I don't like to give my opinion.

3 T: Ok, thank you. How about you?

4 P2: I think we can't take so much time. The teacher is very busy and has lots to teach.

5 T: All right, What about you? Could you give more information when you answer a question?

6 P3: I think sometimes I can use more English but it would take longer. And I fear making mistakes because the more I speak, the less fluently I can speak. I feel embarrassed when I make mistakes.

7 T: How about you?

8 P4: I think so too.

9 T: Could you give me a longer answer now? Do you often shop online?

10 P4:[The student smiles and pauses for thought and replies in English]No, I don't. I usually go to shops.

\section{REFERENCES}

[1] Amy B.M.Tsui.(2000). English Conversation. Shanghai: Shanghai Foreign Language Education Press.

[2] Brown, H.D. (1994). Teaching by Principles: An Interactive Approach to Language Pedagogy. Englewood Cliffs, New Jersey: Prentice Hall.

[3] Chaudron,G.(1988). Second Language Classroom. Cambridge: Cambridge University Press

[4] Ellis,R. (1994).The Study of Second Language Acquisition. Oxford: Oxford University Press.

[5] Holland, R and Shortall, T. (1997). Classroom Research and Research Methods. Birmingham: The Center for English Language Studies.

[6] Jack C.Richards and Theodore S.Rodgers.(2000).Approaches and Methods in Language Teaching. Beijing: Foreign Language Teaching and Research Press

[7] Larsen-Freeman, D. \& M.H. Long. (1991). An Introduction to Second Language Acquisition Research. London: Longman.

[8] Nunan,D. (1989).Understanding Language Classroom. New York: Prentice HALL.

[9] Nunan,D. (1991). Language Teaching Methodology. New York: Prentice HALL

[10] Richards,J.C. and Lockhart,C.(1996). Reflective Teaching in Second Language Classrooms. Cambridge: Cambridge University Press.

[11] Thornbury, S. (1996). Teachers research teacher talk. ELT Journal 50 / $4: 279$ - 287.

[12] Wittrock,M.C..(1988).Handbook of Research on Teaching. New York: Macmillan

[13] Wang dexing,(1998). The Analysis of English Discourse and intercultural communication. Beijing: Beijing Language Culture University Press

[14] Xu jiujiu,(1995).Discourse Analysis of twenty years. Beijing: Foreign language Teaching and Research Press

Weihua Yu was born in Qingdao, China in 1968. She received her M.A. degree in linguistics from Ocean University of China, China in 2006.

She is currently an associate professor in the School of Foreign Languages, Qingdao University of Science and Technology, Qingdao, China. Her research interests include foreign linguistics and applied linguistics as well as second language acquisition. 